courts in $\operatorname{Re} R,{ }^{7}$ a case involving a 15 year old girl suffering from episodes of psychotic illness. The girl's refusal to continue with drug treatment, articulated during a period of lucidity, was overruled by the court on a variety of grounds. Lord Donaldson said in his judgment that where there was more than one person or body who could give consent, treatment would be vetoed only where all those who could consent had refused to do so. A parent has a right to consent to the treatment of a minor, and this right lasts as long as minority does (that is, until the age of 18 years). This would appear to suggest that a competent child (that is, a child capable of understanding the implication of what is being proposed) who declined treatment might still be treated legally if either the parent consents or the court exercises wardship authority and authorises treatment. The court in $R e R$ point out, however, that the consent of the parent in such a case would not mean that the treatment had to be given; the minor's wishes should carry great weight in the doctor's decision making. This is rather difficult to square with current notions of adolescent competence, and indeed with the philosophy underlying the Gillick decision. For this reason it is possible that a future court, faced with such a conflict, would restrict the application of the principle suggested in $\operatorname{Re} R$ to those cases where (i) the rationality of the child is in doubt (and where there would therefore be doubt as to capacity), or where (ii) the child is considered too young to make an informed decision. There is no real difficulty in holding that a 14 or 15 year old who places his or her life in jeopardy by refusing treatment is too young to have the capacity to make a decision of that significance. This may be done on the grounds that a refusal of treatment

\section{Molluscum contagiosum}

Molluscum contagiosum is a self limiting cutaneous viral infection, especially common in children. It produces characteristic pale pupules, which usually cause little discomfort. Indeed for most patients, attempts at treatment and limitation of activities associated with spread of the infection may cause greater distress.

Molluscum contagiosum virus (MCV) belongs to the poxviridae; like other members of this family it is a DNA virus which replicates in the cytoplasm of the host cell and is especially adapted to epidermal cells. The only significant host is man and MCV cannot be grown in tissue culture or eggs. Restriction endonuclease analysis permits classification of MCV into at least two types, named 1 and 2, of which type 1 is much the commoner, but there is as yet no consistent evidence relating the virus type to the clinical appearance of the lesions or to their anatomical distribution. ${ }^{12}$

\section{Epidemiology}

Infection follows contact with an infected person or contaminated objects. It is assumed that epidermal injury facilitates inoculation of the virus, but infection of intact skin may also be possible. In hot countries, where close contact between lightly clad children is frequent, molluscum contagiosum is commonest in young children, the incidence peaking for example in Fiji between the ages of 2 and 3 years. ${ }^{3}$ In more developed countries the infection is commoner in school age children and correlates with the use of swimming pools, ${ }^{34}$ although the precise mode of transmission in this situation is unknown. In a Japanese study involving over 7,000 children, the incidence of molluscum contagiosum was $7 \cdot 5 \%$ among swimmers and $3 \cdot 6 \%$ among non-swimmers. ${ }^{4}$

In adults transmission between sexual partners is recog- requires a greater degree of capacity than the giving of consent does.

(6) Scotland is different, and the basic question of ability to consent is resolved in a recent statute. Under the Age of Legal Capacity (Scotland) Act, 1991, a child under the age of 16 may give a valid consent provided that, in the opinion of a medical practitioner, he or she is capable of understanding the nature and possible consequences of the procedure or treatment. Two points might be made: the determination of competence is left entirely to the doctor, and nothing is said about the case of a competent child who withholds consent. In the latter case, if there were a serious threat to the child's health, the courts would probably override the child's refusal on the grounds suggested above, namely that consent and refusal involve different degrees of capacity.

\section{Faculty of Law,}

ALEXANDER MCCALL SMITH

University of Edinburgh,

Old College, South Bridge,

Edinburgh EH8 $9 Y L$

1 Meyers DW. Parental rights and consent to medical treatment of minors. In: Mason JK, ed. Paediatric forensic medicine and pathology. London: Chapman and Hall, 1989: 428-40.

2 Mason JK, McCall Smith RA. Law and medical ethics. 3rd Ed. London: Butterworths, 1991:231-5.

3 [1986] AC 112.

4 [1981] 1 WLR 1421

5 [1989] 3 WLR 252

6 [1990] 3 All ER 930.

7 [1991] 3 WLR 592.

nised, and such infections usually occur on genital, perineal, pubic, and neighbouring skin. Transmission of molluscum contagiosum to a child during sexual abuse must be possible in principle, but does not appear to have been recorded. Innocently acquired childhood molluscum contagiosum is often widespread and lesions are frequently seen on and near genital and perineal skin. Therefore sexual transmission of molluscum contagiosum to a child should be suspected only if there is other evidence of sexual abuse.

\title{
Immunity
}

Specific antibodies against MCV can be detected in the majority of infected patients, but their biological significance is unknown. The importance of cell-mediated immunity is inferred $^{5}$ from occasional reports of widespread infections in patients immunosuppressed by disease or on immunosuppressive treatment and especially those with HIV infection. ${ }^{6}$ Atopic eczema and use of stronger topical steroids are sometimes associated with more widespread infections.

\section{Natural history}

The incubation period is estimated at between two weeks and six months, though the source of infection is seldom reliably identified. In the immunocompetent patient, individual lesions regress mostly within two months, although solitary lesions may persist for up to five years. New lesions may be due to virus acquired at the time of initial infection, but are probably more commonly due to autoinoculation. The whole infection clears usually within six to nine months, but occasionally persists for a few years. Lesions may appear after apparently successful treatment, 
and it is suggested that a lesion free period of four months should be required before the patient can be regarded as cured. Reinfection is possible but uncommon.

\section{Clinical features}

Molluscum contagiosum may affect any part of the skin surface, but it is rare on palms, soles, and mucous membranes. Lesions are typically spread over an anatomical region such as an axilla and adjacent arm and chest wall, or perineum and upper thighs, but sporadic lesions may be more widely scattered presumably due to autoinoculation. In patients with HIV disease and AIDS, multiple and refractory lesions are particularly common on the face.

The lesions of molluscum contagiosum are typically shiny, pale hemispherical papules, 2 to $5 \mathrm{~mm}$ across, often with a central pore or dimple ('umbilication'). Careful inspection may reveal tiny papules in adjacent skin, best seen with a hand lens. Larger lesions occasionally occur, especially if solitary. The clinical appearance is usually diagnostic. The expression of thick white ('cheesy') material from the centre of the lesion, for example by squeezing with forceps laid across the skin surface, would be corroboratory, but is seldom appreciated by young children. Atypical, usually solitary, lesions may be diagnosed histologically after curettage.

Resolution, spontaneous or after self induced or therapeutic trauma, proceeds through an inflammatory phase with erythema and crusting, often resulting in a small superficial scar. Disrupted lesions bleed, sometimes profusely. Eczema in adjacent skin is occasionally seen, and is commoner and more marked in those with atopic eczema. Conjunctivitis may accompany eyelid lesions.

\section{Treatment}

Affected patients should be advised to avoid contact sports, swimming pools, and shared baths and towels until the infection is clear.

Molluscum contagiosum lesions are vulnerable to physical damage; anything which disrupts an individual lesion will lead to its resolution. Scratching by the patient often helps in this way, although spread of the infection may occur. Superficial curettage, shaving with a sharpened wooden spatula, and expression of the body of the lesion by forceps, have all been used. Such methods are usually followed by an application of a silver nitrate stick, phenol, or strong iodine solution. Chemical methods alone, however, are seldom useful. If cryotherapy is available it is now regarded as the treatment of choice. Briefer freezes are required than for warts of a similar size. Because of the likelihood of subsequent development of further lesions, several treatment session two to four weeks apart should be anticipated. The degree of pain caused by this relatively gentle cryotherapy is variable, but it is unlikely to be tolerated by most children under 10 years of age. The prior use of a topical local anaesthetic such as EMLA cream containing lignocaine and prilocaine (Astra) often helps. ${ }^{7}$ Large solitary lesions may be removed by curettage and diathermy after injection of local anaesthetic, permitting histology if required, but such lesions are rare in children. A weak, or occasionally medium strength, topical steroid may be used for associated eczema. Secondary bacterial infection may require an appropriate antibiotic.

In young children, especially if the molluscum contagiosum affects difficult sites such as eyelids, attempts at treatment may be frightening, and it is best in these circumstances to reassure the parents that the infection is not serious and will eventually resolve spontaneously.

Department of Dermatology,

ALLAN S HIGHET

York District Hospital,

Wigginton Road,

York YO3 $7 \mathrm{HE}$

1 Porter CD, Blake NW, Archard LC, et al. Molluscum contagiosum virus types in genital and non-genital lesions. Br $\mathcal{F}$ Dermatol 1989;120:37-40.

2 Schol\% J, Rosen-Wolff A, Bugert J, et al. Epidemiology of molluscum contagiosum using genetic analysis of the viral DNA. $f$ Med Virol contagiosum $1989 \cdot 27 \cdot 87-90$.

3 Postlethwaite R, Watt JA, Hawley TG, et al. Features of molluscum contagiosum in the north-east of Scotland and in Fijian village settlements. contagiosum in the north-east of Scotland and in

fournal of Hygiene (Cambridge) 1967;65:281-91. Niizeki $K$, Kano $O$, Kondo Y. An epidemic of molluscum contagiosum relationship to swimming. Dermatologica 1984;169:197-8.

5 Highet AS, Kurtz J. Viral infections. In: Champion RH, Burton JL, Ebling FJG, eds. Textbook of dermatology. Oxford: Blackwell 1992:876-9.

6 Katzman M, Carey JT, Elmets CA, et al. Molluscum contagiosum and the acquired immunodeficiency syndrome: clinical and immunological details of two cases. $\mathrm{Br} \mathcal{F}$ Dermatol 1987;116:131-8.

7 Rosdahl I, Edmar B, Gisslen H, et al. Curettage of molluscum contagiosum in children: analgesia by topical application of a lidocaine/prilocaine cream (EMLA). Acta Derm Venerol (Stockh) 1988;68:149-53. 